\title{
PERSEPSI ANGGOTA MUI BALIKPAPAN TENTANG PRAKTIK MAPACCI PRAPERNIKAHAN DI KELURAHAN MANGGAR BARU BALIKPAPAN TIMUR
}

\author{
Muh. Zaim Azhar \\ Sekolah Tinggi Ilmu Syariah (STIS) Hidayatullah Balikpapan \\ zaimazhar86@yahoo.com \\ Nasrullah \\ Sekolah Tinggi Ilmu Syariah (STIS) Hidayatullah Balikpapan \\ nasrullahnur97@gmail.com
}

\begin{abstract}
Abstrak
Penelitian ini berawal dari adanya praktik upacara mapacci sebelum akad nikah pada masyarakat Bugis di Kelurahan manggar baru Balikpapan Timur. Yang disinyalir dalam prosesnya tidak sesuai dengan aturan syariat Agama. Praktik yang dilakukan adalah bemandi antara calon mempelai, baik itu lakilaki maupun perempuan, dengan keyakinan bahwa tujuannya adalah membersihkan jiwa lahir dan batin atas segala dosa dan kesalahan yang telah dilakukan, ritual ini juga diyakini oleh masyarakat setempat dapat membersihkan diri dari penghalang yang dapat menghambat pernikahan karena akan melakukan ikrar yang suci, serta mengundang berkah dan rahmat Allah. Meskipun maksud dan tujuannya sangat baik akan tetapi bertolak belakang dengan hukum syariat. Dalam permasalahan ini persepsi anggota MUI Balikpapan berbeda-beda ada yang sepakat karena tujuan dan maksudnya adalah baik, namun yang lain mengatakan bahwa praktik ini tidak sesuai dengan aturan agama Islam sehingga masyarakat harus diberi pencerahan agar budaya ini tidak terus menerus dilakukan. Oleh karena itu kesimpulan dari penelitian ini adalah bahwasanya praktik mapacci ini adalah merupakan budaya atau adat istiadat yang keliru atau disebut dengan 'urf fāsid, Karena tidak sesuai dengan tuntunan ajaran agama Islam.
\end{abstract}

\section{Keywords: Persepsi, MUI Balikpapan, Praktik, Mapacci}

\section{A. Pendahuluan}

Manusia adalah makhluk hidup yang Allah swt telah tetapkan di muka bumi ini untuk saling membutuhkan serta ketergantungan satu dengan lainya, serta berpasang-pasangan baik dalam kehidupan manusia, hewan serta tumbuh-tumbuhan guna memungkinkan untuk terjadinya perkembangbiakan. Allah swt telah menetapkannya dalam Q.S Ar-Rum [30] :21

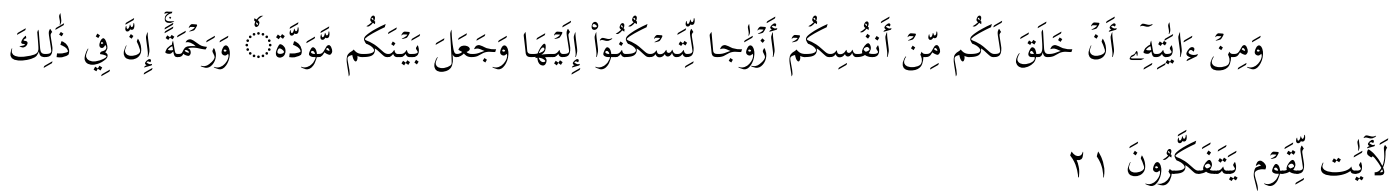

Hubungan perkawinan bagi seorang laki-laki dan perempuan merupakan 
kebutuhan yang tidak bisa dipisahkan dalam kehidupan bagi manusia. Sebab hubungan ini sangat erat kaitannya dibandingkan dengan hubungan sosial lainya. Pernikahan adalah hal yang sangat sakral di mana semua ketentuannya telah ditetapkan oleh syariat yaitu hubungan sepasang laki-laki dan perempuan akan menjadi sah apabila terpenuhi syarat dan rukun pernikahan.

Islam datang dengan kesempurnaannya, mengubah ketahanan umat manusia yang jauh dari syariat Islam dan mengatur hubungan individu dengan aturan yang sangat suci dan menjadikannya mulia. Ada hubungan persaudaraan, hubungan persahabatan dan hubungan pernikahan. Hubungan pernikahan adalah hubungan yang sangat kuat dalam pandangan Islam. Dalam Alquran disebut mis̄āqan ghaliẓ̄han (hubungan perjanjian yang kuat). Pernikahan terjadi antara muslim dan muslimat yang telah balig untuk membuat rumah tangga yang tenteram, penuh kasih sayang serta melahirkan keturunan yang baik.

Islam adalah agama yang sangat sempurna yang telah dibawa oleh Rasulullah saw sebagai agama terakhir dan tidak ada lagi agama setelahnya dikarenakan Allah telah menyempurnakan agama Islam serta memudahkan bagi pemeluknya dalam setiap ajaran yang telah disyariatkan.

Begitu pula dalam pernikahan, cukup memenuhi rukun dan syaratnya maka pernikahan dalam Islam sudah menjadi sah. Adapun kebiasaan dalam masyarakat Bugis terdapat ritual mapacci bagian dari pernikahan yang sering dilakukan oleh nenek moyang mereka kemudian dilanjutkan oleh keturunannya sampai saat ini. Kebiasaan ini terus terulang bahkan sebagian masyarakat Bugis sudah menganggap bahwa mapacci adalah suatu hukum atau aturan yang wajib dilakukan sehingga apabila ada pernikahan tanpa melalui tahapan tersebut maka pernikahannya tidak sah.

Praktik mapacci juga terjadi pada suku Bugis yang berdomisili di kel. Manggar baru, Balikpapan Timur. Mereka meyakini bahwa sebelum pernikahan dilangsungkan maka calon pengantin harus melalui tahapan mapacci. Praktik mapacci diyakini oleh masyarakat setempat dapat membersihkan diri dari penghalang yang dapat menghambat pernikahan. Bagi masyarakat Bugis yang mayoritas beragama Islam, pernikahan merupakan satu perjalanan baru yang harus dilewati oleh jiwa yang bersih melalui ritual mapacci, jiwa yang sebelumnya mungkin sempat ternoda maka dibersihkan terlebih dahulu dengan dihadiri oleh sanak keluarga di tempat kediaman masing-masing.

Mapacci itu sendiri dilaksanakan pada malam hari, mapacci sangat kental dengan nuansa batin, dengan keyakinan bahwa segala sesuatu yang baik dan upaya 
yang baik pula. Upacara adat mapacci melibatkan sanak keluarga untuk direstui kepada calon mempelai dalam menempuh kehidupan selanjutnya sebagai suami istri serta mendapatkan keberkahan dari Allah.

Mapacci dipahami dan diyakini oleh masyarakat Balikpapan Timur selain sebagai sarana untuk mendapatkan keberkahan juga diartikan sebagai sarana untuk memperoleh kesucian jiwa dan raga sehingga tak jarang dijadikan sebagai salah satu syarat yang harus ada dalam pernikahan. Hal ini ditegaskan dalam firman Allah swt di dalam Q.S az-Zukhruf [43]:22

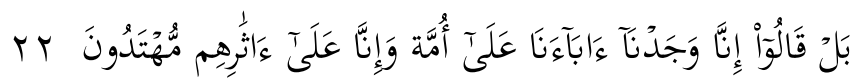

Ibnu Katsir menafsirkan bahwasanya maksud dari lafaz



Artinya: "Mereka tidak memiliki sandaran dalam kesyirikan melainkan ikutikutan dengan bapak-bapak dan kakek-kakek mereka karena mereka adalah satu umat, dalam hal ini juga dalam satu agama."

Bukan hanya ikut-ikutan, akan tetapi dari awal pelaksanaan mapacci sebelum pernikahan sudah memiliki niat yang bertentangan dengan syariat Islam. Hal ini sejalan dengan hadis Rasulullah saw:

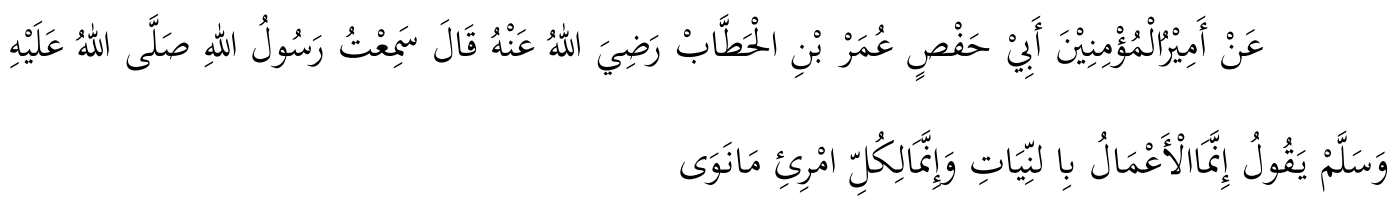

Artinya: Dari Amiril Mukminin Abi Hafsh Umar bin Khattab ra. Berkata aku mendengar Rasulullah saw bersabda "Sesungguhnya amal perbuatan itu disertai niat dan setiap orang mendapatkan balasan amal sesuai dengan niatnya". (HR, Bukhari dan Muslim)

Islam tidak mensyaratkan adanya tradisi tertentu yang harus dilakukan sebelum pernikahan dilangsungkan, tetapi realitas pada umumnya masyarakat melakukan ritual atau tradisi yang mereka yakini sebelum pernikahan, dengan tujuan mendapatkan keberkahan bagi kedua calon mempelai supaya terwujudnya tujuan yang akan dicapai dari pernikahan yaitu sakinah mawaddah warahmah.

Tujuan mapacci yaitu agar kedua calon pengantin pernikahan memperoleh kesiapan yang sudah benar-benar siap, dengan hati yang suci serta ikhlas untuk memasuki rumah tangga, dengan mapacci maka kedua mempelai telah 
membersihkan segala jiwa dan raganya juga termasuk mapacci ati (bersih hati), mapacci nawa-nawa (bersih pikiran), mapacci panggaukan (bersih tingkah laku dan perbuatan), mapacci ateka (bersih itikat).

Pelaksanaan ritual mapacci dilaksanakan pada malam hari sebelum pernikahan akan dilaksanakan pada keesokan harinya. Adat mapacci ini dilaksanakan oleh kedua calon mempelai dengan tempat yang terpisah, biasanya dilaksanakan pada kediaman masing-masing. Adat mapacci ini dimulai dengan pembacaan barazanji untuk memanjatkan doa untuk Rasulullah saw sebagai bentuk kecintaan kepadanya, dan untuk memperoleh keberkahan dan bagi calon pengantin serta keluarga besar calon kedua mempelai.

Fenomena ini yang melatar belakangi peneliti merasa perlu untuk mengangkat sebuah permasalahan mengenai praktik mapacci dari sudut pandang yang berbeda, yaitu persepsi anggota MUI Balikpapan. Sebagai lembaga yang berkompeten dalam memberikan tanggapan langsung, pemberi fatwa bagi umat Islam baik diminta maupun tidak diminta. Karena MUI adalah representasi pemerintah di mana keterlibatannya adalah mutlak. Serta menjadi penghubung antara ulama' dan umara'.

\section{B. Metode Penelitian}

Penelitian ini menggunakan teknik field research (penelitian lapangan) yaitu dengan mengadakan penelitian langsung ke lapangan untuk mendapatkan dan mengumpulkan data serta mengamati permasalahan dalam penelitian.

Sifat penelitian ini yaitu penelitian deskriptif analitik yaitu dengan mendeskripsikan bahan kajian dari berbagai sumber yang didapat yang berkaitan dengan pokok masalah, kemudian menganalisisnya serta menginterpretasikan terhadap data tersebut.

Metode pengumpulan data dalam penelitian ini yaitu peneliti menggunakan tiga metode, pertama adalah pengamatan, yaitu dengan mencermati secara langsung terhadap gejala-gejala atau objek yang diteliti dengan tujuan untuk meyakini kebenaran data yang diperoleh dari wawancara. Kedua, wawancara yaitu berkomunikasi secara langsung serta tanya jawab peneliti dengan responden secara sistematis berdasarkan permasalahan dan tujuan penelitian, ketiga dokumentasi yaitu mencari data mengenai hal-hal atau variabel berupa catatan, transkip, surat kabar, majalah, dan sebagainya yang ada hubungannya dengan topik pembahasan 
yang diteliti. ${ }^{1}$

Teknik pengolahan data dan analisis data peneliti menggunakan beberapa langkah, pertama, Klasifikasi yaitu mereduksi data yang ada dengan cara menyusun serta mengklasifikasi data yang telah diperoleh dalam pola tertentu atau permasalahan tertentu untuk mempermudah permasalahannya. Kedua, mengedit yaitu memperbaiki kesalahan-kesalahan dengan melakukan pengecekan kemudian menyeleksi terhadap data yang diperoleh. ${ }^{2}$

Teknik analisis data Yaitu cara mengelola data menjadi informasi agar karakteristik data tersebut mudah dipahami dan bermanfaat untuk solusi permasalahan, terutama dengan hal yang berkaitan dengan penelitian.

\section{Tentang Mapacci}

Mapacci adalah nama sebuah upacara adat yang berasal dari Provinsi Sulawesi Selatan. Mapacci yaitu kata kerja dari "mapaccing" artinya bersih atau suci. Mapacci adalah suatu kegiatan yang bertujuan atau diyakini dapat membersihkan segala sesuatu yang dapat menghambat pernikahan. Kemudian perkembangan mapacci sering dikaitkan dengan salah satu rangkaian kegiatan atau bagian dari pernikahan Bugis-Makassar yang sudah menjadi turun temurun.

Mapacci dipahami oleh masyarakat sebagai salah satu syarat yang harus dilakukan oleh calon pengantin baik dari laki-laki maupun dari pengantin perempuan sebelum pernikahan di langsungkan, terkadang sehari sebelum akad pernikahan di langsungkan hal ini sudah menjadi turun temurun. ${ }^{3}$ Tidak diketahui dengan pasti kapan sejarah awal kegiatan mapacci ditetapkan sebagai syarat atau kewajiban bagi adat suku Bugis yang harus dilakukan sebelum prosesi pernikahan. Akan tetapi menurut kabar yang berkembang dari kalangan generasi tua praktik mapacci telah mereka warisi sebelum kedatangan Islam dan Kristen di tanah Bugis-Makassar. ${ }^{4}$ Oleh sebab itu kegiatan mapacci sudah menjadi budaya atau adat yang mendarah daging dan sulit dipisahkan dari ritual perkawinan Bugi-Makassar.

\section{Tahapan Praktik Mapacci}

1 Sutrisno Hadi, Metodologi Research (Yogjakarta, Yayasan Penelitian Fakultas Universitas Gajah Mada,1998)., 193.

2 Abdul Mutholib, Metode Penelitian Pendidikan Islam, (Solo: Antasari Press, 2006). 40.

${ }^{3}$ Abdillah Halim, "Tradisi Mapacci Dalam Proses Pernikahan Masyarakat Bugis Perspektif Al'Urf.', Skripsi, Malang: Universits Maulana Malik Ibrahim, 2018), 28. t.d

${ }^{4}$ Syahrul. "Mapacci dan Nilai Filosofinya Bagi Masyarakat Bugis-Makassar" Diakses pada 5 Maret, 2020. https://www.google.com/amp/s/5500967. 
Sebelum pernikahan dilangsungkan calon pengantin terlebih dulu harus melaksanakan praktik mapacci karena hal tersebut menjadi bagian dalam pernikahan suku Bugis yang berdomisili di Balikpapan Timur. Sebelum pernikahan dilangsungkan calon pengantin harus terlebih dahulu melaksanakan tahapantahapan dalam proses praktik mapacci diantaranya:

\section{a. Memakai Baju Adat}

Dalam acara mapacci pengantin harus di-makeup terlebih dahulu, kemudian memakai baju adat Bugis, untuk pengantin laki-laki yaitu "baju lengan panjang berbentuk seperti jas, memakai sarung sutera (lipa sabbe) serta celana (parocci) sebagai bawahannya, dan peci atau tutup kepala (passapu)".5 Sedangkan untuk calon pengantin perempuan yaitu “(baju bodo) baju ini merupakan baju yang sangat tipis dan menerawang sehingga harus menggunakan sarung lipa, sehingga sebagai bawahnya, memakai sanggul dan tusuk sanggul, memakai bando berbentuk setengah lingkaran berwarna emas juga perhiasan seperti gelang, kalung, dan gelang lengan terbuat dari kepingan emas. ${ }^{6} \mathrm{Hal}$ ini menjadi salah satu syarat awal untuk memulai atau melaksanakan praktik mapacci, hal ini sudah menjadi tradisi bagi masyarakat Bugis yang tak pernah berubah. Setelah memakai pakaian adat Bugis barulah calon pengantin di arak ke tempat duduk atau tempat yang telah disediakan untuk memulai mapacci.

\section{b. Mabbarazanji.}

Memulai praktik mapacci dengan pembukaan atau masyarakat Bugis sering menyebutnya mabarasanji atau bara'sanji di mana seluruh undangan, sanak keluarga termasuk calon pengantin ikut membaca barasanji sebagai syi'ar yang berisi pujipujian, ringkasan tentang keturunan Nabi Muhammad saw dan kelahirannya, sejarah kehidupannya, keistimewaan dan sifat-sifat baginda Muhammad saw . Hal tersebut sebagai bentuk kecintaanya kepada Nabi, diyakini akan membawa keberkahan bagi para tamu undangan, dan bagi kehidupan rumah tangganya kelak. ${ }^{7}$

\section{c. Proses Mapacci}

Prosesi mapacci baru dilaksanakan apabila benda atau alat yang di percaya sudah lengkap, para sesepuh, sanak saudara, serta para undangan yang mendapat mandat untuk meletakkan pacci telah tiba. Prosesi mapacci di mulai oleh indo' botting

5 Siti Hajar Mahfuzah, "Praktik Mapacci Prapernikahan Masyarakat Suku Bugis Di Kelurahan Manggar Baru" (Skripsi, STIS Hidayatullah, 2018), 70

${ }^{6}$ Ibid.,73-74.

${ }^{7}$ Ibid., 79 
kemudian diikuti oleh keluarga terdekat dan para undangan yang telah diberi mandat atau kepercayaan untuk meletakkan pacci, saat peletakan pacci terkadang ada di antara mereka mencium dahi calon pengantin sebagai bentuk kasih sayang dari keluarga. ${ }^{8}$ Mapacci diyakini dengan makna bahwa dapat menyucikan jiwa dan raga sebelum memasuki bahtera rumah tangga dan agar calon pengantin dapat hidup bahagia seperti mereka meletakkan pacci. Setelah prosesi mapacci dilaksanakan maka para tamu undangan yang telah diberi mandat untuk meletakkan pacci pada calon pengantin diberikan amplop yang berisi uang sebagai rasa tanda terima kasih. ${ }^{9}$

Adapun alat dalam pelaksanaan praktik mapacci yang mengandung arti harapan dan doa untuk kebahagiaan dan kesejahteraan calon pengantin dengan makna simbolis yaitu: ${ }^{10}$

1. Daun pacci (daun pacar) Yaitu sebagai simbol kebersihan dan kesucian yang diyakini bertujuan untuk membersihkan kedua mempelai. Penggunaan pacci menandakan bahwa calon pengantin telah bersih hatinya sebelum melaksanakan akad nikah pada esok harinya serta kehidupan selanjutnya sebagai pasangan suami istri sampai maut memisahkan. Daun pacci setelah dihaluskan disimpang dalam wadah yang telah disediakan biasanya disebut bekkeng yang dimaknai kesatuan jiwa, serta kerukunan dalam kehidupan keluarga dan kehidupan masyarakat.

2. Bantal atau pengalas kepala yang disusun secara vertikal berisi kapuk atau kapas yang terbuat dari kain, diyakini dan dipercaya sebagai lambang kesuburan dan mappakalebbi (kemuliaan atau kehormatan) serta diharapkan dapat memberikan kesuburan dan kehormatan bagi kedua calon pengantin.

3. Sarung Sutera 7 lembar yang disusun di atas bantal mengandung arti sebuah harga diri dan sebagai lambang keistikamahan serta ketekunan yang diharapkan selalu tekun dan istikamah seperti pembuat sarung yang tiap hari menenun dan menyusun sehelai demi sehelai benang sehingga menjadi sebuah sarung yang siap pakai. Dengan sikap istikamah serta ketekunan ini diharapkan calon pengantin dapat mengambil pelajaran dan hikmah dari pembuat sarung sutera sehingga dapat diamalkan dalam bahtera kehidupan rumah tangga. Sarung bagi masyarakat Bugis dahulunya digunakan sebagai penutup aurat melambangkan martabat dan

\footnotetext{
${ }^{8}$ Ibid., 63.

${ }^{9}$ Ibid., 71-72.

${ }^{10}$ Ibid., 65-68.
} 
harga diri. Diharapkan agar calon pengantin perempuan senantiasa menjaga harkat dan martabatnya, tidak menimbulkan siri' (rasa malu) di tengah-tengah masyarakat .

4. Daun pisang diyakini sebagai lambang kehidupan atau satu pohon yang bisa dinikmati banyak orang dengan pernikahan diharapkan berguna dan dapat membawa keberkahan bagi masyarakat. Daun pisang dilambangkan sebagai kehidupan yang berkesinambungan sebagaimana pohonnya yang setiap saat terjadi pergantian daun, hal ini yang menjadi keyakinan bagi masyarakat Bugis di artikan sebagai kelanjutan keturunan. Daun pisang tidak akan mati dan layu hal ini selaras dengan tujuan pernikahan yaitu melahirkan dan mengembangkan keturunan atau melanjutkan keturunan.

5. Daun nangka diyakini sebagai lambang kejujuran dan kesucian menjadi modal utama dalam mengarungi kehidupan rumah tangga sebagai pasangan suami istri dalam masyarakat Bugis. Daun nangka diletakkan di atas daun pisang sebanyak 7 atau 9 lembar dimaknai sebagai pemaknaan menasa (harapan) atau cita-cita agar calon pengantin nantinya setelah mengarungi bahtera rumah tangga memiliki harapan untuk membina rumah tangga dalam keadaan sejahtera dan mudah rezeki.

6. Kelapa muda dan gula merah yaitu melambangkan agar calon pengantin kelak saling melengkapi serta bersama-sama menghadapi manis pahitnya setelah memasuki kehidupan rumah tangga.

7. Tai bani, patti atau lilin yaitu di maknai sebagai suluh penerangan, agar kedua calon pengantin nantinya selalu mendapat petunjuk dan penerangan dari Allah juga sebagai simbol lebah yang selalu senantiasa rukun dan tidak mengganggu satu sama lain, serta di artikan sebagai lambang saling melengkapi di antara kedua calon pengantin dalam mengarungi pahit manisnya dalam bahtera rumah tangga.

8. Piring yang berisi wenno (kembang beras) yaitu beras yang sangrai hingga mengembang yang di maknai mpenno riale (berkembang dengan baik), ${ }^{11}$ juga diartikan sebagai penyatu yang diyakini agar kedua calon pengantin setelah memasuki bahtera rumah tangganya selalu dilandasi cinta kasih, penuh dengan kedamaian dan kesejahteraan.

\section{Tujuan Mapacci.}

11 "Seputar Pernikahan" http://www.seputarpernikahan.com/prosessi-mapcci-pernikahan- 
Adapun tujuan dari praktik mapacci pranikah ala suku Bugis yaitu12 (a)membersihkan jiwa dan raga ke dua calon pengantin baik sebelum memasuki bahtera rumah tangganya. (b) Agar supaya terhindar dari nasib sial serta ancaman kehancuran dalam rumah tangga, setelah memasuki bahtera rumah tangganya. (c)Membangun kesiapan kedua calon pengantin sebelum memasuki kehidupan rumah tangganya. (d)Untuk membersihkan segala sesuatu yang dapat menghambat pernikahannya. ${ }^{13}$

\section{Persepsi MUI Berkenaan Dengan Mapacci}

Persepsi Anggota MUI Balikpapan timur Tentang Praktik Mapacci Sebelum Akad Nikah. bahwasanya seluruh anggota MUI Balikpapan sepakat bahwa praktik mapacci di Balikpapan Timur tidak sesuai dengan syariat Islam karena di dalam pelaksanaannya, mulai dari awal pelaksanaannya sampai selesai terdapat pelanggaran syariat yang tidak sesuai dengan konsep Islam. Tetapi dalam menyikapi pelaksanaan praktik mapacci mereka terbagi menjadi dua, dari lima orang yang diwawancarai ada dua orang sepakat, sedang tiga orang lainnya menyatakan tidak sepakat terhadap praktik tersebut. Adapun pendapat mereka;

Pertama, pendapat yang menyatakan setuju dengan aturan praktik mapacci, dengan alasan, bahwasanya praktik mapacci bertujuan utuk memberikan pemahaman kepada kedua calon pengantin bahwasanya besok kamu akan menikah maka bersihkanlah dirimu terlebih dahulu dari dosa, kebiasaan yang jelek saat masih bujang, membersihkan kebiasaan buruk, kesyirikan yang ada pada dirinya. Jadi ada pesan Islam yang sangat mulia yang ingin disampaikan lewat praktik mapacci, paccingi alenu (bersihkanlah dirimu), disimbolisasikan lewat tradisi mapacci, hal ini sesungguhnya sejalan dengan perintah agama sebagaimana Firman Allah swt dalam surah Al-Muddatsir ayat 4, sehingga tujuan utama dari tradisi mapacci yaitu untuk membersihkan baik secara lahir maupun secara batin terhadap kedua calon pengantin sebelum memasuki bahtera rumah tangga.

Alasan pertama bertujuan untuk membimbing calon pengantin bahwa engkau akan menikah maka bersihkanlah dirimu terlebih dahulu melalui perantara alat-alat yang diyakininya agar terhindar dari nasib buruk, agar terhindar dari hal-hal yang dapat merusak hubungan rumah tangganya kelak setelah memasuki bahtera rumah tangga. Sehingga menjadi keluarga sakinah, mawaddah, dan warahmah. Hal ini

\footnotetext{
12 Siti Hajar Mahfuzhah, Praktik Mapacci Prapernikahan., h. 80

13 Paluseri, Penetapan Warisan Budaya., h. 307
} 
mungkin tidak bertentangan dengan syariat Islam karna ada pesan Islami yang ingin disampaikan lewat praktik mapacci. Alasan kedua tentang praktik mapacci adalah suatu waşilah (perantara) agar doa yang di panjatkan kepada Allah cepat terijabah, adapun masyarakat yang meyakini bahwa praktik mapacci harus ada sebelum pernikahan dan menjadikannya salah satu syarat dalam pernikahan, latar belakang timbulnya keyakinan tersebut serta menjadi alasan sebagian masyarakat Bugis dikarenakan kurangnya pemahaman masyarakat tersebut terhadap syariat Islam (ajaran Islam) maka di sini perlu pembinaan agar supaya hal ini tidak terulang terusmenurus agar orang yang melaksanakannya bukan termasuk orang yang buruk akan tetapi malah sebaliknya yaitu orang yang taat kepada Allah karena telah menjalankan syariat Islam.

Kedua: anggota MUI yang lain berpendapat bahwasanya mereka tidak setuju dengan praktik mapacci dengan alasan bahwasanya Islam itu sudah sempurna tidak perlu ditambah, dikurangi apalagi dihilangkan, dan menjalankan syariat Allah itu lebih utama dari pada mengutamakan aturan atau syariat yang dibuat oleh manusia tentang praktik mapacci adapun alasan mereka mengapa tidak setuju dengan praktik mapacci yaitu: pertama, jika dilihat dari sisi syariat dari awal pelaksanaan sampai selesai hampir tidak ada manfaatnya malah menyusahkan calon pengantin baik dari pihak laki-laki maupun dari pihak perempuan, sementara Islam malah memudahkan sebagaimana dalam surah An-Nur ayat: 32. jadi orang yang ingin melaksanakan pernikahan itu dimudahkan sementara mapacci ini justru malah merepotkan orang yang ingin menikah. alasan kedua dalam syariat Islam jelas dilarang, karena mengandung unsur kesyirikan di mana dalam pelaksanaannya mereka menjadikan bagian dari salah satu syarat serta meyakini bahwa tanpa dilaksanakan praktik mapacci maka akan terjadi nasib sial setelah mengarungi bahtera rumah tangganya.

\section{E. Tinjauan Hukum Islam}

Tinjauan hukum Islam terhadap persepsi anggota MUI Balikpapan adalah dengan menggunakan kaidah al-'urf bahwa tradisi mapacci jika dilihat dari segi kajian objeknya maka tradisi mapacci termasuk 'urfal-'amali karena sudah menjadi tradisi pada masyarakat, khususnya masyarakat Bugis yang berdomisili di Kelurahan Manggar Baru. Di mana hal tersebut dilakukan terus-menerus dalam bentuk perbuatan. Jika dilihat dari segi cakupannya al-'urf maka tradisi mapacci termasuk dalam 'urf al-khaş karena praktik mapacci hanya berlaku di daerah atau wilayah tertentu khususnya masyarakat Bugis yang berdomisili di Kelurahan Manggar Baru dan hal ini tidak berlaku bagi suku lain. 
Kemudian jika dilihat dari segi keabsahannya, praktik mapacci bisa masuk pada kategori al-'urfal-fāsid atau al-'urfal-şhohih hal ini tergantung pada faktor diri masing-masing, keyakinan serta dalam menyikapi dan tata cara pelaksanaannya sesuai dengan sudut pandang Islam di mana Al-Quran dan Hadits sebagai syariat dan tuntunan hidup, telah menjelaskan tentang kedudukan tradisi ('urf) dalam agama itu sendiri, karena nilai tradisi ('urf) yang diyakini dapat mengantarkan keberuntungan, keberkahan, keberhasilan bagi masyarakat lebih khusus dalam rumah tangganya. Akan tetapi di samping eksistensi adat atau tradisi tersebut tidak sedikit yang menimbulkan polemik. Seperti tradisi praktik mapacci di mana tradisi tersebut menjadi salah satu syarat yang harus ada sebelum pernikahan karena hal tersebut diyakini dan dipercaya dapat membersihkan diri dari sesuatu yang dapat menghambat pernikahannya, membawa keberkahan dan keberuntungan bagi calon pengantin agar kelak setelah memasuki bahtera rumah tangganya tidak terjadi mala petaka.

Setiap peraturan, anjuran pasti akan membawa dampak positif begitu halnya dengan larangan yang diindahkan pasti akan membawa manusia kepada kemaslahatan, keberuntungan bagi kehidupannya. salah satu kemaslahatan bagi manusia yaitu menjauhkan dirinya dari tradisi nenek moyang yang bertentangan dengan syariat Islam sebagaimana Firman Allah swt dalam Q.S Al-Baqarah : 170

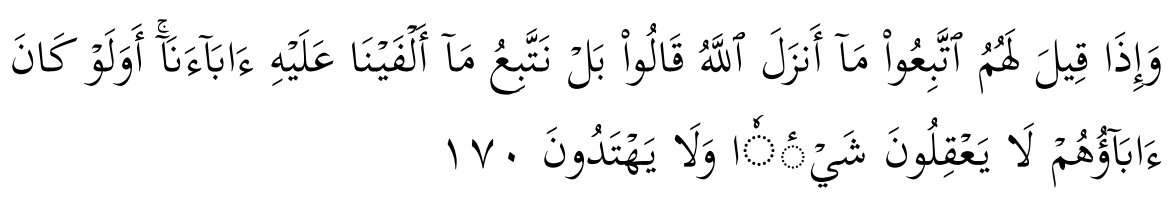

Adapun ayat selanjutnya sebagaimana Firman Allah swt dalam Q.S AlMaidah : 104



Pada kedua ayat di atas dapat dipahami bahwa tradisi mapacci tidak memiliki sandaran yang jelas melainkan hanya ikut-ikutan terhadap nenek moyangnya. Hal tersebut memberikan pemahaman kepada kita tentang orang-orang yang lebih patuh terhadap ajaran dan perintah nenek moyang mereka dari pada Syariat Allah dan Rasulullah saw.

Sesuai dengan persepsi anggota MUI Balikpapan tentang praktik mapacci prapernikahan merupakan tradisi dan telah menjadi ciri khas tersendiri, praktik mapacci ini menyalahi syariat karena dalam praktiknya tidak menggunakan 
ketetapan hukum Islam. Jika dipandang dari hukum Islam sangat bertentangan dengan hukum syariat, sehingga praktik mapacci menjadi adat yang bersifat negatif, jika disinkronisasikan dengan ilmu kajian ushul fiqh maka disebut 'urf fāsid yakni al'urf al-fāsid (kebiasaan yang dianggap rusak), adalah kebiasaan yang berlaku di tengah-tengah masyarakat sedangkan hal tersebut bertentangan dengan naş (ayat atau hadis), dengan kata lain 'urf yang menghalalkan sesuatu yang di haramkan atau membatalkan sesuatu yang wajib.

$$
\text { كُلهُ شَرْطِ بِغَيْرِ حُكُم الشَرْعِعِ بَاطِلَ }
$$

Artinya : Setiap syarat yang tidak ditetapkan dalam hukum syar'i maka ia batil.14

Kemudian hal tersebut dikuatkan dalam Matan Naẓam kaidah-kaidah Fikih.

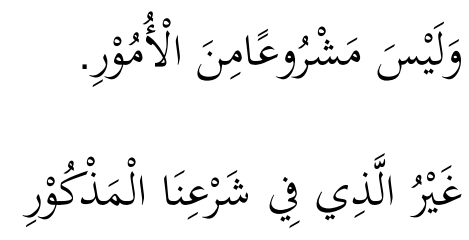

Artinya : Setiap perkara yang tidak disebutkan di dalam Syariat kita, dianggap bukan sebagai Syariat. 15

Hal ini perlu dipertegas bahwa syariat atau peraturan yang telah ditetapkan oleh Allah dan Rasulnya lebih diutamakan dari pada harus mengikuti adat, tradisi, budaya atau peraturan yang dibuat oleh Manusia, jika melihat ketentuan hukum yang dibuat oleh manusia dan dengan melihat kaidah, maka ketentuan hukum yang dibuat oleh manusia tidak dapat didahulukan.

Maka praktik mapacci di kelurahan manggar baru Balikpapan Timur merupakan tradisi ('urf) lebih banyak mengandung mudarat dari pada maslahat jika dilihat dari sisi manfaatnya. Akan tetapi jika dilihat dari kultur kebudayaan ('urf) maka dia adalah kekayaan atau ciri khas dari sekian banyaknya suku yang ada di Indonesia

${ }^{14}$ H. Abdul Mujib, Kaidah-Kaidah Ilmu Fiqh, (Jakarta: Karam Mulia, 2001), 87

15 Abdurrahman bin Nashir bin Abdullah As-Sa'diy, Manzhumah Al-Qawa'id Al-fiqhiyyah, (Solo: Pustaka Arafah, 2018), Cet-1, 27. 


\section{F. Kesimpulan}

Pertama, bahwasanya seluruh anggota MUI Balikpapan sepakat menyatakan bahwa praktik mapacci di Balikpapan Timur tidak sesuai dengan syariat Islam karena di dalam pelaksanaannya, mulai dari awal ritual tersebut sampai selesai terdapat pelanggaran syariat yang tidak sesuai dengan konsep Islam. Namun dalam praktik pelaksanaannya, anggota MUI Balikpapan berbeda pendapat. pendapat yang pertama menolak aturan pelaksanaan praktik mapacci prapernikahan yang harus menjadi salah satu syarat yang harus ada dalam pernikahan, karena setiap hukum yang bertentangan dengan syariat Islam harus dihapus atau direvisi ulang dan membuat aturan yang sesuai dengan syariat Allah dan Rasulnya. Pendapat kedua setuju dengan Adat atau tradisi tersebut, karena lewat tradisi mapacci ada semangat keagamaan yang harusnya tersampaikan lewat tradisi mapacci itu, dengan alasan para da'i harus memberikan pencerahan dan penyuluhan pada masyarakat agar betul-betul memahami syariat Allah dan Rasulnya.

Kedua, persepsi anggota MUI Balikpapan tentang praktik mapacci di Balikpapan Timur jika ditinjau dengan Hukum Islam adalah merupakan adat khusus ('urf khaş) yaitu sesuatu yang berlaku pada suku atau lingkungan tertentu. Kemudian jika ditinjau dari segi keabsahannya 'urf terdapat dua pendapat, bahwa yang sepakat dengan praktik ini menyatakan ini termasuk 'urf şahih adalah sesuatu yang dibolehkan karena dalam pelaksanaannya terdapat pesan Islam yang ingin di sampaikan lewat praktik mapacci, adapun masyarakat Bugis yang berkeyakinan bahwa praktik mapacci adalah sesuatu yang harus ada, sehingga menjadi salah satu syarat atau bagian dari pernikahan, hal tersebut mereka yakini dikarenakan kurangnya pemahaman dalam syariat Islam, sehingga di sini peran para dai sangat dibutuhkan untuk memberi pemahaman dan edukasi pada masyarakat. adapun yang tidak sepakat dengan praktik ini menyatakan bahwa tidak dibolehkan karena merupakan 'urffāsid yakni (dilarang) adalah sebuah kebiasaan yang terjadi di tengahtengah masyarakat khususnya masyarakat Bugis, di mana dalam pelaksanaan praktik mapacci terdapat pelanggaran syariat sehingga hal tersebut jelas bertentangan dengan syariat atau naşh (al-quran dan hadits). Apapun ketetapan adat selama itu bertentangan dengan syariat Islam, maka hal tersebut tertolak dan harus direvisi agar sejalan dengan syariat Islam. 


\section{Daftar pustaka}

Alu Syaikh. Abdullah bin Muhammad bin Abdurrahman bin Ishaqq, Lubaabut Tafsir Ibni Katsir., 283.

An-Nawawi. Imam, Terjemahan Hadits Arba'in An-Nawawi, (Jakarta: Al-I'tishom Cahaya Ummat 2001), Cet-1.

Hamdani. Al- Risalah Nikah, diterjemahkan oleh Agussalim judul, Hukum Perkawinan Islam. Jakarta: Pustaka Amani, 1980

Halim. Abdillah, "Tradisi Mapacci Dalam Proses Pernikahan Masyarakat Bugis Perspektif Al-Urf.", Skripsi, Malang: Universitas Maulana Malik Ibrahim, 2018.

Mutholib. Abdul, Metode Penelitian Pendidikan Islam, Solo: Antasari Press, 2006. Mujib, H. Abdul, Kaidah-Kaidah Ilmu Fiqh, Jakarta: Karam Mulia, 2001

Mahfuzah. Siti Hajar, "Praktik Mapacci Prapernikahan Masyarakat Suku Bugis Di Kelurahan Manggar Baru" Skripsi, STIS Hidayatullah, 2018.

Nurlaela, Pandangan Muslimat Hidayatullah Tentang Poligami, Skripsi (Balikpapan: Perpustakaan STIS Hidayatullah,2011

AM, Masyarakat Bugis, Wawancara Pribadi,19 November 2019.

Paluseri, Penetapan Warisan Budaya Takbenda Indonesia, (PDF, Jakarta: Kementrian Pendidikan dan Kebudayaan, 2018

Rahma. Abd, http//www.scribd.com/doc/49374883/ Adat-Perkawinan-Bugis. Di Akses 6 november 2019

Sutrisno Hadi, Metodologi Research Yogjakarta, Yayasan Penelitian Fakultas Univers itas Gajah Mada,1998

Syahrul. " Mapacci dan Nilai Filosofinya Bagi Masyarakat Bugis-Makassar" Diakses pada 5 Maret, 2020. https://www.google.com/amp/s/5500967.

"Seputar Pernikahan" http://www.seputarpernikahan.com/prosessi-mapccipernikahan-adat-bugis/.

Sa'diy. Abdurrahman bin Nashir bin Abdullah As-, Manzhumah Al-Qawa'id Alfiqhiyyah, Solo: Pustaka Arafah, 2018, Cet-1.

Tsani. Ali farkhan, Kajian al Baqarah ayat 42, ( Jakarta ), 2 April,.I. 